\title{
PENINGKATAN KEMAMPUAN KOMUNIKASI MATEMATIK MELALUI PEMBELAJARAN MATEMATIKA REALISTIK
}

\author{
Oleh: \\ ${ }^{1)}$ Saleh Haji, ${ }^{2)}$ M. Ilham Abdullah \\ Program Studi Pendidikan Matematika, FKIP Universitas Bengkulu \\ ${ }^{1}$ salehhaji25@gmail.com, ${ }^{2}$ ilhamabdullah418@gmail.com
}

\begin{abstract}
ABSTRAK
Tujuan penelitian ini adalah untuk mengetahui pencapaian dan peningkatan kemampuan komunikasi matematik siswa Sekolah Menengah Pertama Kota Bengkulu melalui Pembelajaran Matematika Realistik. Metode penelitian yang digunakan adalah kuasi eksperimen dengan non-equivalent control group design. Hasil penelitian sebagai berikut. Pembelajaran Matematika Realistik lebih efektif dalam pencapaian dan peningkatan kemampuan komunikasi matematik siswa dibandingkan pembelajaran konvensional. Besarnya pencapaian kemampuan komunikasi matematik siswa yang diajar melalui pembelajaran matematika realistik adalah 63,96 dan pembelajaran konvensional adalah 47,46. Sementara itu, besarnya peningkatan kemampuan komunikasi matematik siswa yang diajar melalui pembelajaran matematika realistik adalah 0,51 dan pembelajaran konvensional 0,24.
\end{abstract}

Kata Kunci : Komunikasi Matematik, Pembelajaran Matematika Realistik

\begin{abstract}
The purpose of this study is to determine the achievement and improvement of students' mathematical communication ability in Bengkulu City Junior High School through realistic mathematics learning. The method used is a quasi-experimental non-equivalent control group design. The results of this study as follows. The realistic mathematics learning is more effective in the achievement and improvement of students' mathematical communication ability than conventional learning. The magnitude of the achievement of students' mathematical communication ability in realistic mathematics learning is 63,96 and conventional learning is 47,46 . Meanwhile, the magnitude of the improvement of students' mathematical communication ability is realistic mathematics learning is 0,51 and conventional learning is 0,24 .
\end{abstract}

Keywords: mathematical communication, realistic mathematics learning

\section{PENDAHULUAN}

\section{A. Latar Belakang}

Kemampuan berkomunikasi dalam pembelajaran matematika di sekolah menengah pertama kurang mendapat perhatian dari para guru. Guru cenderung menekankan pada kemampuan berhitung, pemecahan masalah, dan penalaran. Sehingga kemampuan komunikasi matematika siswa lemah. Siswa kurang dapat mengkomunikasikan ide-ide matematiknya secara jelas dan benar, baik secara lisan maupun tulisan. Hasil penelitian Rohaeti (2003), Wihatma (2004), Purniati (2004) menyimpulkan bahwa kemampuan komunikasi matematik siswa Sekolah Menengah Pertama rendah. 
Kemampuan komunikasi matematik merupakan salah satu standar proses dalam pembelajaran matematika di sekolah. Van De Wall, Karp, Jennifer, and Williams (2000) mengemukakan 5 standar proses dalam pembelajaran matematika yakni: 1. Problem solving, 2. Penalaran dan bukti, 3. Komunikasi, 4. Koneksi, dan 5. Representasi. Standar proses kemampuan komunikasi tersebut memberikan batasan terhadap aspek-aspek komunikasi yang diajarkan pada sekolah. Kemampuan komunikasi matematik merupakan kemampuan siswa dalam mengkomunikasikan ide-ide matematik pada orang lain. Baroody (1993) menjelaskan bahwa pembelajaran matematik harus dapat membantu siswa mengkomunikasikan ide matematik melalui 5 aspek yaitu: representing, listening, reading, discussing, dan writing.

Baroody (1993) juga menjelaskan bahwa pentingnya komunikasi dalam pembelajaran matematika, karena mathematics as language dan mathematics learning as social activity. Sebagai bahasa, matematika digunakan orang dalam menyampaikan ide dengan menggunkan simbol dan pengertian yang memiliki arti tunggal. Matematika yang digunakan di sekolah dalam pembelajaran matematika menghasilkan berbagai aktivitas siswa dan guru dalam mendiskusikan matematik. Selain aktivitas di dalam kelas (sekolah), matematik juga digunakan oleh masyarakan dalam aktivitas sosialnya. Seperti dalam aktivitas perdagangan,pertanian, pertambangan dan lain-lain.

Untuk mengatasi kelemahan komunikasi matematik siswa perlu dilakukan perubahan pembelajaran, dari pembelajaran konvensional ke pembelajaran non-konvensional. Firdaus (2006) menjelaskan bahwa pembelajaran non-konvensional meningkatkan kemampuan komunikasi matematik siswa. Salah satu pembelajaran non-konvensional tersebut adalah pembelajaran matematika realistik (PMR). Pembelajaran matematika realistik memandang bahwa matematika sebagai suatu aktivitas manusia. Sebagai suatu aktivitas, matematika sebagai suatu sarana yang memungkinkan terjadinya interaksi antar manusia.

Beberapa hasil penelitian menunjukkan bahwa PMR mampu meningkatkan aktivitas belajar siswa. Baik aktivitas fisik maupun mental. Karena PMR memuat berbagai kegiatan fisik maupun mental. Seperti kegiatan diskusi, refleksi, dan penemuan konsep maupun algoritma. Khasanah (2007) menemukan bahwa Pendidikan Matematika Realistik Indonesia (PMRI) dapat meningkatkan aktivitas siswa dalam pembelajaran keliling dan luas bangun datar. Begitu juga, hasil penelitian Al Muhari (2008) menghasilkan bahwa PMRI dapat meningkatkan kreativitas belajar siswa.

\section{B. Rumusan Masalah}

1. Apakah terdapat peningkatan kemampuan komunikasi matematik siswa yang diajar melalui pembelajaran matematika realistik?

2. Apakah pencapaian kemampuan komunikasi matematik siswa yang diajar melalui pembelajaran matematika realistik lebih baik daripada pembelajaran konvensional?

\section{KAJIAN PUSTAKA}

\section{A. Kemampuan Komunikasi Matematik}

Secara harfiah, komunikasi memiliki arti pengiriman dan penerimaan berita atau pesan antara dua orang atau lebih (Surayin, 2003). Ini berarti, dalam komunikasi memuat tiga komponen yaitu isi pesan/berita, proses pengiriman/penerimaan pesan, dan orang yang mengirim/menerima pesan tersebut. Dalam konteks pembelajaran matematika, isi pesan/berita 
dalam komunikasi yaitu matematika. Suriasumantri, J.S. (2007) mengemukakan bahwa matematika merupakan bahasa yang melambangkan serangkaian makna dari pernyataan yang ingin kita sampaikan. Matematika berbentuk simbol yang memiliki makna tertentu. Simbolsimbol tersebut dapat berupa fakta, konsep, prinsip, maupun algoritma. Contoh fakta adalah bilngan $\pi$, variabel sebagai suatu konsep, teorema phytagoras sebagai suatu prinsip, dan langkah-langkah penyelesaian operasi hitung dua buah bilangan merupakan algoritma.

Secara istilah, Greenes and Schulman (1996) mengemukakan pengertian komunikasi matematik sebagai suatu kemampuan dalam: a. Menyatakan ide matematik melalui ucapan, tulisan, demonstrasi, dan melukiskannya secara visual, b. memahami, menafsirkan, dan menilai ide yang disajikan dalam tulisan, lisan, atau visual, c. Mengkonstruk, menafsirkan, dan menghubungkan bermacam-macam representasi ide dan hubungannya. Berdasarkan pengertian ini, komunikasi matematik lebih detail. Isi pesan/berita berbentuk ide matematik. Proses pengiriman/penerimaan isi pesan/berita dalam bentuk tulisan, lisan, representasi. National Council of Teacher of Mathematics (2000) menjelaskan bentuk proses komunikasi matematik sebagai: membuat ilustrasi dan interpretasi, berbicara atau berdiskusi, menyimak atau mendengar, menulis, dan membaca. Bentuk kegiatan prosesnya adalah menyatakan, memahami, menafsirkan, dan menghubungkan isi pesan (matematika).

Kemampuan komunikasi matematik merupakan suatu kemampuan dalam mengkomunikasikan matematik. Hulukati (2005), menjelaskan komunikasi matematik sebagai suatu kemampuan siswa dalam mengekspresikan, menginterpretasi, mengevaluasi ide-ide dan notasi matematika melalui tulisan, lisan, dan mendemonstrasikannya secara verbal. Dari pengertian tersebut, kemampuan komunikasi matematik memiliki karakteristik. Sumarmo (2000), menjelaskan karakteristik kemampuan komunikasi sebagai berikut:

a. Membuat hubungan benda nyata, gambar, dan diagram ke dalam ide matematik.

b. Menjelaskan ide, situasi dan relasi matematika secara lisan maupun tulisan dengan benda nyata, gambar, grafik, dan gambar.

c. Menyatakan peristiwa sehari-hari dalam bahasa atau simbol matematika.

d. Mendengarkan, berdiskusi, dan menulis tentang matematika, membaca dengan pemahaman suatu representasi matematik.

e. Membuat konjektur, menyusun argumen, merumuskan definisi dan generalisasi.

f. Menjelaskan dan membuat pertanyaan tentang matematika.

Van De Wall, Karp, Jennifer, and Williams (2000) mengemukakan indikator dari kemampuan komunikasi matematik siswa di sekolah sebagai berikut:

a. Mengatur dan mengkonsulidasikan pemikiran matematika siswa melalui komunikasi.

b. Mengkomunikasikan pemikiran matematika siswa secara koheren dan jelas kepada temanteman, guru, dan lain-lain.

c. Menganalisis dan mengevaluasi pemikiran matematik.

d. Menggunakan bahasa matematik untuk mengekspresikan ide-ide matematik secara tepat.

Indikator-indikator tersebut menunjukkan adanya kemampuan komunikasi pada seorang siswa maupun guru. Sedangkan National Council of Teacher of Mathematics (2000) menjelaskan indikator kemampuan komunikasi matematik sebagai berikut, yaitu:

a. Mengungkapkan ide matematik secara tertulis maupun lisan.

b. Merumuskan definisi dan membuat generalisasi.

c. Menyajikan matematika dengan pengertian. 
d. Menjelaskan pertanyaan matematik.

e. Menghargai daya dan keindahan matematik.

Menurut Hendriana (2009), kegiatan komunikasi tentang matematik berkaitan dengan kegiatan merefleksi proses kognitif, mendeskripsikan prosedur, menggambarkan metakognisi, dan berkomunikasi dengan orang lain tentang matematika. Kegiatan komunikasi dalam matematik adalah mencatat secara matematik dan merepresentasikan sesuatu dengan simbol. Sedangkan komuniksi dengan matematik sebagai berikut: matematika sebagai alat pemecahan masalah, mencari solusi alternatif, menginterpretasikan argumen, dan menggunakan pemecahan masalah matematik.

\section{B. Pembelajaran Matematika Realistik}

Haji dan Abdullah (2014) mengemukakan pembelajaran matematika realistik sebagai suatu pola yang sistematis dalam merancang pembelajaran matematika yang efektif untuk mencapai tujuan pembelajaran matematika dengan bertumpu pada kreativitas siswa dalam melakukan doing mathematics yang memandang matematika sebagai suatu aktivitas manusia melalui kegiatan memecahkan masalah kontekstual, merumuskan model, mengkaitkan berbagai topik, berinteraksi dengan berbagai sumber, memanfaatkan berbagai potensi sendiri, berdiskusi, melakukan refleksi, memanfaatkan fenomena pendidikan, mengeksplor, dan akhirnya menemukan (invention) berbagai konsep (prinsip) dan algoritma matematik. Dari pengertian tersebut, pembelajaran matematika realistik memiliki karakteristik. Treffers (1987) menjelaskan lima karakteristik dari pembelajaran matematika realistik, yaitu: 1. The use of context, 2. The use of models, 3. The use of students', 4. The interactive character of teaching process, and 5. The intertwinement of varios learning strands.

\section{METODE PENELITIAN}

Sampel penelitian ini adalah siswa kelas VIIA SMPN 24 Kota Bengkulu yang terdiri atas 19 siswa. Sedangkan populasi penelitian ini adalah siswa kelas VII SMPN 24 Kota Bengkulu yang terdiri atas 85 siswa.

Instrumen penelitian ini berbentuk tes kemampuan komunikasi matematik sebanyak 3 item. Hasil analisis tes kemampuan komunikasi matematik dengan menggunakan software Anates sebagai berikut. Rata-rata skor $=60,79$, standar deviasi $=22,75$, korelasi $\mathrm{XY}=0,71$, reliabilitas $=0,83$ (Haji dan Abdullah, 2014).

Disain penelitian ini adalah a quasi-experimental design by the non-equivalent control group (Cohen, Manion and Morrison, 2000):

$$
\begin{array}{llll}
\text { Experimental } & \mathrm{O}_{1} & \mathrm{X} & \mathrm{O}_{2} \\
\text { Control } & \mathrm{O}_{3} & & \mathrm{O}_{4}
\end{array}
$$

$\mathrm{X}$ adalah perlakuan berupa pembelajaran matematika realistik 


\section{HASIL DAN PEMBAHASAN}

\section{Peningkatan Kemampuan Komunikasi Matematik (KKM)}

Hasil uji hipotesis menunjukkan bahwa terdapat peningkatan kemampun komunikasi matematik siswa yang diajar melalui pembelajaran matematika realistik. Seperti tampak pada Tabel 1. Peningkatan kemampuan komunikasi matematik siswa yang diajar melalui pembelajaran matematika realisti sebesar 0,51. Sedangkan peningkatan kemampuan komunikasi matematik siswa yang diajar melalui pembelajaran konvensional sebesar 0,24. Peningkatan kemampuan komunikasi matematik siswa lebih besar daripada peningkatan kemampuan komunikasi matematik siswa yang diajar melalui pembelajaran konvensional.

Tabel 1. Hasil Uji - $t$ N-gain KKM Siswa

\begin{tabular}{|c|c|c|c|c|c|c|c|}
\hline Kelompok Data & $N$ & $\begin{array}{l}\text { Rata- } \\
\text { rata }\end{array}$ & $\begin{array}{c}\text { Beda } \\
\text { Rata-rata }\end{array}$ & $t$ & $D f$ & $\begin{array}{c}\text { Sig. } \\
\text { (2-arah) }\end{array}$ & $\mathrm{H}_{0}$ \\
\hline $\begin{array}{l}\text { N-gain KKom } \\
\text { Eksperimen }\end{array}$ & 27 & 0,51 & \multirow{2}{*}{0,27} & \multirow{2}{*}{3,396} & \multirow{2}{*}{49} & \multirow{2}{*}{0,001} & \multirow{2}{*}{ Ditolak } \\
\hline $\begin{array}{l}\text { N-gain KKom } \\
\text { Kontrol }\end{array}$ & 24 & 0,24 & & & & & \\
\hline
\end{tabular}

Sumber: Haji dan Abdullah (2014)

Peningkatan kemampuan komunikasi matematika siswa yang diajar melalui pembelajaran matematika realistik dikarenakan pembelajaran matematika realistik memotivasi siswa untuk melakukan diskusi terhadap teman-temannya dan guru dalam memecahkan masalah kontekstual maupun dalam menemukan suatu konsep dalam matematika. Seperti dalam memecahkan masalah berikut ini, diketahui bilangan-bilangan bulat 786 dan -867. Bilangan mana yang lebih besar? Mengapa? Sebanyak 95\% siswa yang diajar melalui pembelajaran matematika realistik menjawab dengan benar permasalahan tersebut. Hasil diskusi mereka sebagai berikut:

Siswa A : 786 lebih besar daripada -867, karena bilangan positif lebih besar daripada bilangan negatif.

Siswa B : Coba kamu tunjukkan bahwa bilangan positif lebih besar daripada bilangan negatif.

Siswa A : Baik, saya akan tunjukkan bahwa bilangan 786 lebih besar daripada -867, dengan menggunakan gambar garis bilangan sebagai berikut:

$\longleftrightarrow-867 \quad 0 \quad 786$

Siswa B : Mengapa bilangan -867 letaknya di sebelah kiri bilangan 786 dan diantara ke dua bilangan tersebut terdapat bilangan nol?

Siswa A : Karena bilangan -867 merupakan bilangan negatif, sedangkan bilangan 786 merupakan bilangan positif. Bilangan 0 lebih besar daripada bilangan negatif dan lebih kecil daripada bilangan positif.

Siswa B : Oh, kalau begitu saya setuju. 
Sebanyak 73\%, siswa yang diajar melalui pembelajaran konvensional mengalami kesulitan dalam menyelesaikan soal tersebut. Sebanyak 62\%, jawaban siswa salah. Mereka mengatakan bahwa -867 lebih besar daripada 786 . Karena bilangan 8 pada -867 lebih besar daripada bilangan 7 pada 786 . Kegiatan diskusi pada pembelajaran konvensional kurang berkembang. Umumnya, siswa masing-masing menyelesaikan soal tersebut.

\section{Pencapaian Kemampuan Komunikasi Matematik Siswa Yang Diajar Melalui Pembelajaran Matematika Realistik}

Hasil uji Mann Whitney menunjukkan bahwa menerima hipotesis yang menyatakan bahwa terdapat perbedaan pencapaian kemampuan komunikasi matematik siswa yang diajar dengan menggunakan pembelajaran matematika realistik dengan pembelajaran konvensional. Pencapain kemampuan komunikasi matematik siswa yang diajar melalui pembelajaran matematika realistik lebih besar daripada siswa yang diajar melalui pembelajaran konvensional. Kemampuan komunikasi matematik siswa yang diajar melalui pembelajaran matematika realistik sebesar 63,96, sedangkan siswa yang diajar melalui pembelajaran konvensional sebesar 47,46. Hal ini tampak pada Tabel 2 berikut ini.

Tabel 2. Hasil Uji Mann-Whitney Pretes dan Postes KKM Siswa

\begin{tabular}{|c|c|c|c|c|c|}
\hline Kelompok Data & $\begin{array}{c}\text { Rata- } \\
\text { rata }\end{array}$ & $\begin{array}{l}\text { U Mann } \\
\text { Whitney }\end{array}$ & $Z$ & $\begin{array}{c}\text { Sig. } \\
(2-a r a h)\end{array}$ & $\mathrm{H}_{0}$ \\
\hline Pretes KKMM Eksperimen & 32,33 & \multirow{2}{*}{221,500} & \multirow{2}{*}{$-1,950$} & \multirow{2}{*}{0,051} & \multirow{2}{*}{ Diterima } \\
\hline Pretes KKMM Kontrol & 32,00 & & & & \\
\hline Postes KKMM Eksperimen & 63,96 & \multirow{2}{*}{149,500} & \multirow{2}{*}{$-3,306$} & \multirow{2}{*}{0,001} & \multirow{2}{*}{ Ditolak } \\
\hline Postes KKMM Kontrol & 47,46 & & & & \\
\hline
\end{tabular}

Kemampuan komunikasi matematik siswa yang diajar melalui pembelajaran matematika realistik lebih cepat daripada siswa yang diajar melalui pembelajaran konvensional. Karena pada pembelajaran matematika realistik, siswa melakukan kegiatan refleksi dan penemuan. Melalui kegiatan refleksi, siswa memiliki kesempatan untuk memperbaiki kesalahan maupun kekurang tepatan dalam menyelesaikan suatu masalah. Kegiatan refleksi tersebut dilakukan siswa dengan meninjau ulang hal yang telah dilakukannya. Siswa berkomunikasi dengan dirinya sendiri.

Begitu pula dengan kegiatan penemuan. Siswa melakukan komunikasi dengan teman maupun gurunya. Seperti dalam menemukan keliling segitiga. Siswa menggunakan seutas tali untuk mengitari benda berbentuk segitiga. Sehingga siswa menyimpulkan bahwa keliling suatu segitiga adalah jumlah dari ketiga sisinya. Melalui pemahaman seperti ini, sebanyak $77 \%$ siswa dapat menjawab dengan benar soal berikut ini. Keliling suatu segitiga yang panjang sisinya $(\mathrm{a}+6) \mathrm{cm}, 28 \mathrm{~cm}$, dan $12 \mathrm{~cm}$ adalah $180 \mathrm{~cm}$. Berapakan nilai a? Jawaban soal tersebut adalah $\mathrm{a}=134$.

Salah satu cara dalam menjawab soal tersebut sebagai berikut. Ke tiga sisi segitiga digambar dalam satu garis disertai dengan panjangnya. 


\begin{tabular}{ccc}
$(\mathrm{a}+6) \mathrm{cm}$ & $28 \mathrm{~cm}$ & $12 \mathrm{~cm}$ \\
\hline $\mathrm{a}+6+28$ & +12 \\
& $+280 \mathrm{~cm}$ \\
$6+28+12=46$ & \\
$\mathrm{a}=180-46=134$ &
\end{tabular}

Peningkatan dan pencapaian kemampuan komunikasi matematik siswa yang diajar melalui pembelajaran matematika realistik maupun melaui pembelajaran konvensional ditunjukkan pada Gambar 1 berikut ini.

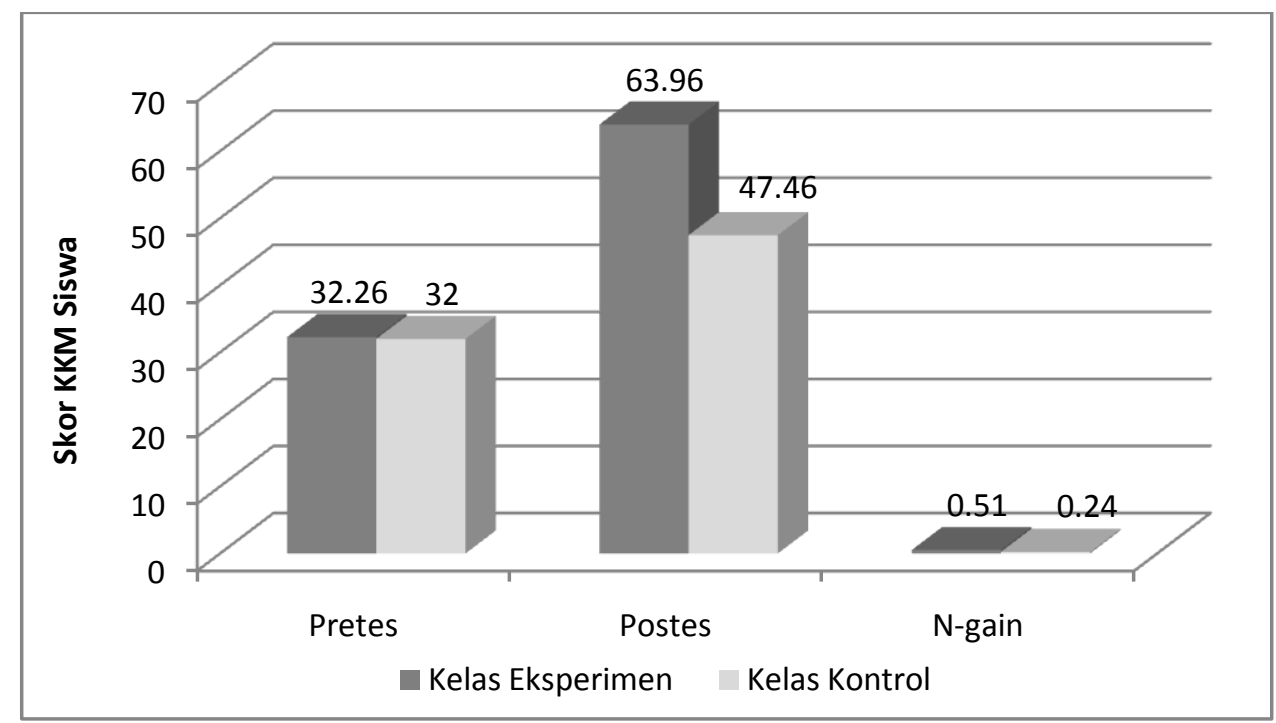

Gambar 1. Peningkatan dan Pencapaian Kemampuan Komunikasi Matematik Siswa

\section{KESIMPULAN DAN SARAN}

\section{A. Kesimpulan}

1. Terdapat peningkatan kemampuan komunikasi matematik siswa yang diajar melalui Pembelajaran Matematika Realistik sebesar 0,51.

2. Pencapaian kemampuan komunikasi matematik siswa yang diajar melalui Pembelajaran Matematika Realistik sebesar 63,96, hal ini lebih besar daripada siswa yang diajar melalui pembelajaran konvensional yakni 47,46.

B. Saran

1. Untuk meningkatkan kemampuan komunikasi matematik siswa, hendaknya guru menerapkan model Pembelajaran Matematika Realistik dengan menekankan pada kegiatan diskusi yang multi arah.

2. Untuk meningkatkan pencapaian kemampuan komunikasi matematik siswa, hendaknya guru menerapkan model Pembelajaran Matematika Realistik dengan menekankan pada kegiatan refleksi dan penemuan selama berlangsung pembelajaran. 


\section{DAFTAR PUSTAKA}

Al Muhari, R. (2008). Penerapan Pendekatan Pendidikan Matematika Realistik Indonesia (PMRI) Untuk Meningkatkan Kreativitas Belajar Siswa. Yogyakarta.

Baroody, A.J. (1993). Problem Solving, Reasoning, and Communicating, K-8. Helping Children Think Methematically. New York: Macmullan Publishing Company.

Cohen, L., Manion, L. and Morrison, K. (2000). Research Mathods in Education. London: Routledge Falmer.

Firdaus (2006). Meningkatkan Kemampuan Komunikasi Matematik Siswa Melalui Pembelajaran dalam Kelompok Kecil Tipe Team Assisted Individualization (TAI) dengan Pendekatan Berbasis Masalah. Tesis. Program Pascasarjana UPI Bandung. Tidak diterbitkan.

Greenes, C. and Sculman, L. (1996). Communication Processis in Mathematical Exploration and Investigations. Virginia: NCTM.

Haji, S. dan Abdullah, M.I. (2014). Model Pembelajaran Matematika Realistik Untuk Menigkatkan Kemampuan Berpikir Matematika Tingkat Tinggi dan Kemandirian Belajar Siswa. Laporan Penelitian. Universitas Bengkulu.

Hendriana, H. (2009). Pembelajaran dengan Pendekatan Metaphorocal Thinking untuk Meningkatkan Kemampuan Pemahaman Matematik, Komunikasi Matematik dan Kepercayaan Dirisiswa Sekolah Menengah Pertama. Disertasi. Sekolah Pascasarjana UPI Bandung. Tidak diterbitkan.

Hulukati, E. (2005). Mengembangkan Kemampuan Komunikasi dan Pemecahan Masalah Matematika Siswa SMP Melalui Model Pembelajaran Generatif. Disertasi. Program Pascasarjana UPI Bandung. Tidak diterbitkan.

Khasanah, F. (2007). Aktivitas Siswa dalam Pembelajaran Keliling dan Luas Bangun Datar Melalui Pendekatan Pendidikan Matematika Realistik Indonesia. Yogyakarta.

National Council of Teacher of Mathematics (2000). Principles and Standard for School Mathematics. Reston: V.A.

Purniati, T. (2004). Pembelajaran Geometri berdasarkan Tahap-Tahap Teori Van Hiele dalam Upaya Meningkatkan Kemampuan Komunikasi Siswa SMP. Bandung: Sekolah Pascasarjana UPI. Tidak diterbitkan.

Rohaeti, E.E. (2003). Pembelajaran dengan Metode IMPROVE Untuk Meningktakan Pemahman dan Kemampun Komunikasi Matematik Siswa SLTP. Tesis. Bandung: Sekolah Pascasarjana UPI. Tidak diterbitkan.

Surayin (2003). Kamus Umum Bahasa Indonesia. Bandung: Yrama Widya.

Suriasumnatri, J.S. (2007). Filsafat Ilmu Sebuah Pengantar Populer. Jakarta: Pustaka Sinar Harapan.

Sumarmo, U. (2000). Alternatif Pembelajaran Matematika dalam Menerapkan Kurikulum Berbasis Kompetensi. Makalah Seminar Nasional FMIPA Universitas Pendidikan Indonesia.

Traffers (1987). Three Dimentions, A Model of Goels in Theory Description in Mathematics Instruction.Dordrecht: Reidel Publishing Company.

Van De Wall, Karp, Jennifer, and Williams (2000). Elementary and Middle School Mathematics Teaching Developmentally.

Wihatma, U. (2004). Meningkatkan Kemampuan Komunikasi Matematik Siswa SLTP melalui Cooperative Learning Tipe STAD. Tesis. Bandung: Sekolah Pascasarjana UPI. Tidak diterbitkan. 